\title{
PENGEMBANGAN SISTEM AKUISISI DATA MENGGUNAKAN NI CDAQ 91 BERBASIS LABVIEW
}

\author{
Anisah $^{1}$, Sudarno $^{2}$ \\ ${ }^{1}$ Mahasiswa Jurusan Fisika, FMIPA Universitas Sriwijaya \\ ${ }^{2}$ Bidang Pengembangan Fasilitas Keselamatan Reaktor, Fasilitas Termohidrolika, Pusat \\ Teknologi dan Keselamatan Reaktor Nuklir -BATAN
}

\begin{abstract}
ABSTRAK
PENGEMBANGAN SISTEM AKUISISI DATA MENGGUNAKAN NI CDAQ 91 BERBASIS LABVIEW. Dalam akuisisi data perlu dilakukan peningkatan kinerja sistem instrumentasi dengan mengembangkan sistem akuisisi data berbasis LabVIEW, salah satunya dengan memastikan data yang didapat benar dan dapat dipercaya. Data tersebut harus melalui proses kalibrasi terlebih dahulu. Dalam eksperimen ini pengkalibrasian dilakukan dengan membandingkan hasil pengukuran temperatur dari termokopel yang tercatat berupa akuisisi data NI cDAQ 91 dengan pengukuran alat ukur standar termometer digital Fluke yang berfungsi sebagai kalibrator. Modul NI cDAQ 91 yang digunakan yaitu channel 1 dan channel 2. Setiap channel ada dua bagian data yang diambil yaitu untuk suhu rendah dengan rentang yang lebih kecil dan suhu tinggi dengan rentang yang lebih besar. Hasil data kalibrasi akan diproses dan dicari hasil ketidakpastiaannya. Setelah melalui proses kalibrasi ternyata hasil datanya tidak berbeda jauh karena tidak mencapai temperatur $1^{\circ} \mathrm{C}$ artinya data hasil kalibrasi tersebut dapat dipercaya dengan kesalahan kurang dari $1^{\circ} \mathrm{C}$.
\end{abstract}

Kata Kunci: Akuisisi Data, NI cDAQ 91, LabVIEW, Kalibrasi

\section{ABSTRACT}

DEVELOPMENT OF DATA ACQUISITION SYSTEM USING NI CDAQ 91 BASED ON $\boldsymbol{L A B V I E W}$. In data acquisition, it is necessary to improve the performance of the instrumentation system by developing a LabVIEW based data acquisition system, one of which is by ensuring that the data obtained is correct and reliable. The data must go through a calibration process. In this experiment the calibration was done by comparing the results of the temperature measurements from the recorded thermocouples in the form of NI cDAQ 91 data acquisition with measurements of the standard Fluke digital thermometer that functions as a calibrator. The NI cDAQ91 module used is channel 1 and channel 2. Each channel has two parts of data taken, namely for low temperatures with smaller ranges and higher temperatures with a greater range. The results of the calibration data will be processed and the results of the uncertainty will be searched. After going through the calibration process it turns out the data results are not much different because it does not reach a temperature of $1{ }^{\circ} \mathrm{C}$ means that the calibration data results can be trusted with errors less than $1{ }^{\circ} \mathrm{C}$.

Keywords: Data Acquisition, NI cDAQ 91, LabVIEW, Calibration 


\section{PENDAHULUAN}

Dalam aplikasi sistem kontrol di industri, kebutuhan untuk pengambilan dan pengolahan data menjadi hal yang biasa dengan jumlah data yang banyak, kompleks dan variatif. Oleh karena itu, dibutuhkan suatu perangkat yang dapat menangani kebutuhan tersebut, salah satunya adalah suatu sistem yang disebut dengan Data Acquisition System (DAS). Pada saat ini yang banyak digunakan ialah sistem akuisisi berbasis personal computer (PC). Kombinasi dari perangkat DAS dengan PC ini dapat melaksanakan berbagai macam keperluan hanya dengan merubah perangkat lunak yang dijalankan di PC.

Salah satu program aplikasi yang cukup terkenal dalam dunia industri adalah LabVIEW yang dibuat oleh perusahaan National Instruments. LabVIEW sendiri digunakan untuk keperluan kontrol akuisisi data yang memiliki keunggulan mudah dalam pembuatan tampilan dengan kreasi tak terbatas untuk interaksi dengan pengguna langsung.

Dalam sebuah instansi/industri seperti BATAN sangat diperlukan adanya suatu sistem instrumentasi yang handal untuk memenuhi fasilitas laboratorium. Laboratorium yang digunakan untuk melakukan penelitian yaitu di kawasan PTKRN di Laboratorium Termohidrolika Eksperimental yang memiliki beberapa fasilitas salah satunya yaitu Fasilitas Simulasi
Sistem Pasif (FASSIP) yang digunakan dalam kajian desain teknis dan keselamatan PLTN. Salah satu komponen utama untuk mengukur perubahan temperatur pada untai uji FASSIP menggunakan sistem akuisisi data dengan jumlah kanal yang banyak.

Tujuan dari pengembangan sistem akusisi data berbasis PC ini untuk mencatat dan merekam data perubahan temperatur yang terjadi pada FASSIP dan menyimpannya dalam PC/komputer, sehingga data yang dihasilkan benar dan dapat dipercaya. Hasil yang akurat dalam suatu pengukuran didapatkan dari proses kalibrasi yang benar juga. Untuk setiap besaran yang terukur terdapat nilai ketidakpastiaan yang perlu dicari agar dapat menentukan seberapa besar kepercayaan dari hasil kalibrasi tersebut. Kalibrasi dalam laporan ini digunakan untuk membandingkan hasil pengukuran temperatur dari termokopel sehingga data yang didapat bisa digunakan sebagai contoh untuk pengembangan sistem akuisis data.

\section{TEORI}

Sebuah sistem akusisi data atau yang dikenal dengan Data-Acquisition System (DAS) merupakan sistem instrumentasi elektronik terdiri dari sejumlah elemen yang secara bersama-sama bertujuan melakukan pengukuran, menyimpan, dan mengolah hasil pengukuran[1]. Tugas utama dari DAS adalah untuk mengakuisisi sinyal dari sensor, 
yang biasanya berupa sinyal analog, mengubahnya menjadi sinyal digital dan memberikannya kepada sistem berikutnya yang akan memanfaatkan sinyal digital tersebut [2] untuk disimulasi dengan menggunakan program aplikasi di PC/computer.

\section{LabVIEW (Laboratory Virtual} Instrumentation Engineering Workbench) merupakan perangkat lunak yang menggunakan bahasa pemrograman grafis dengan layout visual atau menggunakan model aliran data[3]. Program LabVIEW sering disebut juga sebagai Virtual Instruments (VI). Setiap VI terdiri dari tiga bagian utama yaitu: Front Panel, merupakan tampilan antarmuka yang akan tampil dilayar monitor saat program VI di eksekusi. Block Diagram merupakan program utama pada LabVIEW dan sebagai driver dari front panel. Project explorer merupakan hirarki dari struktural program. Posisi atau letak suatu VI pada project explorer sangat menentukan ruang lingkup dan jangkauannya[4]. LabVIEW menawarkan fitur canggih yang membuatnya mudah untuk terhubung ke berbagai perangkat keras dan software lainnya [5].

Program aplikasi yang dijalankan di komputer memanipulasi data mentah yang berasal dari perangkat DAS menjadi informasi yang dapat dimengerti pengguna, kemudian hasil pengolahan data disajikan dalam grafik, tabel atau tampilan visual lainnya. LabVIEW juga menyediakan tooltool untuk penyimpanan data yang dapat dibaca/ditulis dengan program lain seperti Excel dan MS Word. LabVIEW juga menyediakan fungsi-fungsi yang mempermudah pengendalian proses akuisisi data dalam perangkat DAQ [6].

Termokopel (Thermocouple) adalah jenis sensor suhu yang digunakan untuk mendeteksi atau mengukur suhu melalui dua jenis logam konduktor berbeda yang digabung pada ujungnya sehingga menimbulkan efek "Thermo-electric". Efek Thermo-electric pada Termokopel ini ditemukan oleh seorang fisikawan Estonia bernama Thomas Johann Seebeck pada Tahun 1821, dimana sebuah logam konduktor yang diberi perbedaan panas secara gradient akan menghasilkan tegangan listrik. Tegangan listrik diantara dua persimpangan (junction) ini dinamakan dengan Efek "Seeback" [7]. Termokopel yang digunakan pada FASSIP adalah termokopel tipe $\mathrm{K}$. Termokopel tipe $\mathrm{K}$ menggunakan logam nickel-cromium dan nickelalumunium. Termokopel tipe $\mathrm{K}$ memiliki rentang pengukuran dari $-200{ }^{\circ} \mathrm{C}$ sampai dengan $1250{ }^{\circ} \mathrm{C}[3]$.

Kalibrasi adalah kegiatan untuk menentukan kebenaran konvensional nilai penunjukkan alat ukur dan bahan ukur dengan cara membandingkan terhadap standar ukur yang mampu telusur (traceable) ke standar nasional maupun internasional[8]. 
Definisi ketidakpastian (uncertainty) adalah parameter yang menetapkan rentang nilai yang didalamnya diperkirakan terletak nilai kuantitas yang diukur. Jadi bisa diartikan bahwa hasil pengukuran kuantitatif tidak tepat bila dilaporkan sebagai satu angka atau nilai tunggal. Dari hasil pengukuran tersebut kita tidak yakin bahwa nilai tersebut benar, namun akan lebih yakin jika nilai tersebut adalah nilai perkiraan [9]

Fasilitas

Termohidrolika

Eksperimental merupakan laboratorium yang berfungsi untuk penelitian keselamatan termohidrolika reaktor, khususnya untuk reaktor daya atau PLTN. FASSIP atau Fasilitas Simulasi Sistem Pasif juga merupakan sarana eksperimen yang dibangun untuk mengamati fenomena sirkulasi alami pada sistem pendingin reaktor. Salah satu besaran fisik penting yang diamati pada untai uji FASSIP adalah temperatur. Untuk mengamati perubahan temperatur pada untai uji FASSIP digunakan sensor termokopel. Termokopel dipasang pada sekeliling loopnya untuk mengamati perubahan temperatur[3]. Fasilitas FASSIP ini merupakan program yang didanai oleh DIPAPTKRN tahun anggaran 2015-2019 pada kegiatan Kajian Desain Teknis dan Keselamatan PLTN. Fasilitas ini juga digunakan pada project IAEA-CRPI3 dengan periode eksperimen dimulai sejak tanggal 1 Januari 2017 hingga 31 Desember 2019 [10].

\section{METODOLOGI}

Sistem instrumentasi yang digunakan menggunakan modul NI cDAQ 9191 yaitu perangkat akuisisi data dari National Instrument yang dapat membaca 4 keluaran sensor termokopel. Perangkat ini menggunakan koneksi Ethernet untuk berkomunikasi dengan komputer.

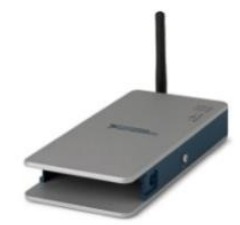

Gambar 1. Modul NI cDAQ 9191

Perangkat yang dibutuhkan ialah Modul NI cDAQ 91 dan PC/komputer yang telah terinstal perangkat lunak LabVIEW. Pekerjaan dimulai dengan merakit sistem instrumentasi dengan menghubungkan salah satu bagian Termokopel tipe - K pada keluaran dari NI cDAQ 91 dan sisi lainnya pada termokopel digital Fluke/ kalibrator untuk dapat mengatur besar temperatur yang diinginkan. Hubungkan modul NI cDAQ 91 dengan $\mathrm{PC} /$ komputer menggunakan kabel Ethernet/router hotspot. Kemudian, lakukan pengaturan Internet Protokol pada laptop untuk dapat berkomunikasi dengan NI cDAQ 91. Setelah laptop dan NI cDAQ 91 terhubung dilanjutkan dengan melakukan pemrograman dengan perangkat lunak LabVIEW. 


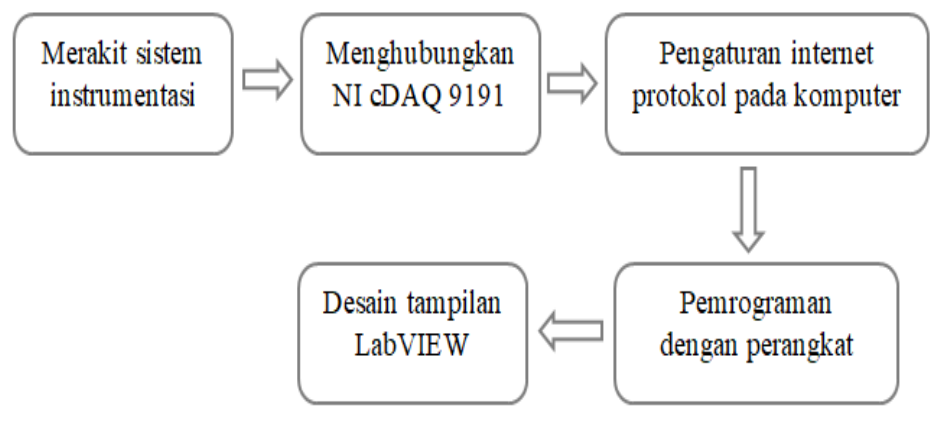

Gambar 2. Diagram alur pembuatan sistem akuisisi data

Hasil pemrograman pada diagram digunakan untuk menjalankan program block LabVIEW ditunjukkan pada Gambar 3. secara terus menerus hingga operator Pada Gambar ini menunjukkan bahwa menghentikannya dengan menekan tombol program akuisisi data terdapat di dalam "stop".

sebuah loop yaitu while loop. While loop

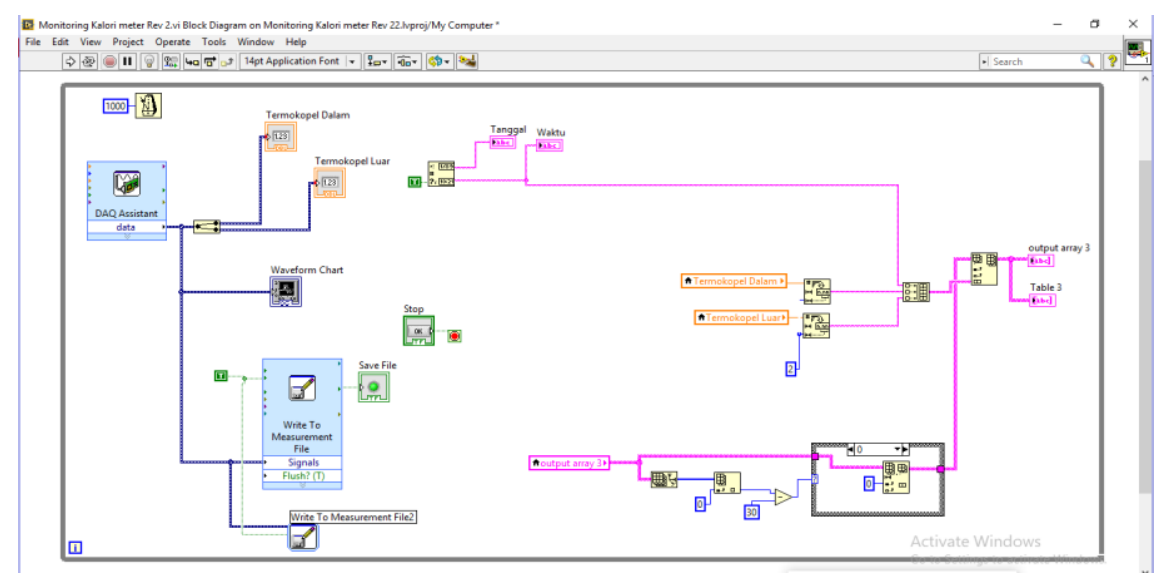

Gambar 3. Diagram block dari program akuisisi data

Jendela ini tidak akan terlihat oleh pengguna saat program dijalankan. Isi dari block diagram dibuat oleh pengguna dengan memanfaatkan fungsi-fungsi yang ada di LabVIEW disesuaikan

dengan program apa yang akan dibuat untuk mempermudah pengendalian proses akuisisi data dalam perangkat DAQ. Dalam hal ini block diagram yang akan dibuat yaitu mengenai monitoring kalorimeter atau menghitung besar dari temperatur yang dihasilkan oleh suatu benda. Setelah selesai merancang isi dari block diagram, selanjutnya isi dari objek-objek pada front fanel ini akan secara otomatis memiliki representasi ikonnya di block diagram, khususnya untuk objek-objek yang membawa data baik data yang masuk dari pengguna ke program, maupun data yang keluar dari pengguna ke program. Objek- 
objek pada jendela front panel akan terlihat oleh pengguna saat program dijalankan. Berikut gambar front panel yang dihasilkan dari perancangan block diagram yang telah dibuat.

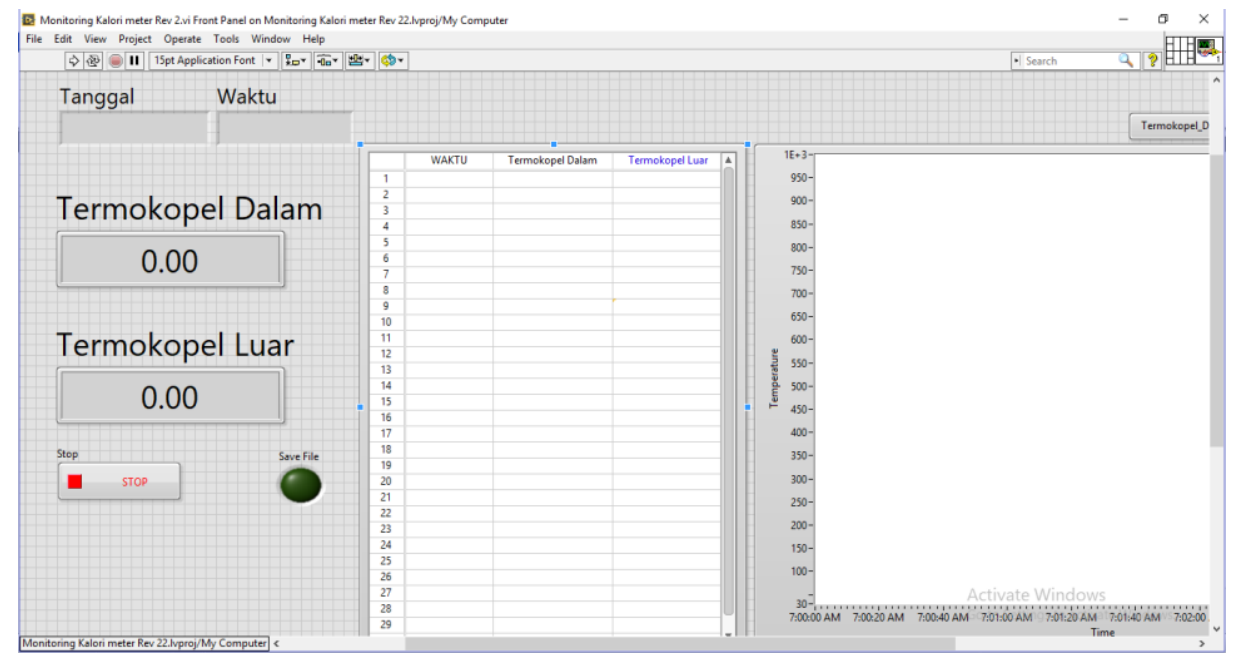

Gambar 4. Tampilan Front Panel dari program akuisisi data

Gambar 4. menunjukkan tampilan digital antarmuka program akuisisi data. Tampilan antarmuka ini menampilkan tampilan digital pembacaan suhu. program akan menampilkan nilai pembacaan suhu saat tombol star monitoring ditekan. Seperti terlihat contoh pada Gambar 4, nilai pembacaan suhunya akan menampilkan angka sesuai dengan pembacaan suhu dari termokopel dalam dan termokopel luar.

\section{Proses Kalibrasi Program Akuisisi Data}

Pada bagian Metode Kalibrasi Program Akuisisi Data dimana terdapat Gambar 2 yang menggambarkan diagram alur pembuatan sistem akuisisi data, dimulai dari perakitan sistem instrumentasinya sampai mendesain tampilan LabVIEW yang telah dijelaskan sebelumnya. Langkah selanjutnya ialah menjelaskan mengenai pengambilan data untuk kalibrasi NI cDAQ 91 sebagai berikut:

1. Buka software LabVIEW, lalu open project Monitoring Kalorimeter, pastikan modul NI cDAQ terhubung dengan laptop/PC

2. NI cDAQ 91 memiliki 4 channel keluaran, dalam percobaan ini hanya channel 1 dan channel 2 yang dipakai

3. Pengambilan datanya dilakukan satu persatu mulai dari menghubungkan channel 1 lalu channel 2 ke termometer digital Fluke dengan menggunakan termokopel tipe-K.

4. Pada program LabVIEW, suhu yang tercatat akan ditampilkan sebagai nilai dari termometer dalam 
5. Sebelum melakukan pengambilan data ukur suhu ruangan terlebih dahulu, data untuk setiap channel yang diambil, terbagi menjadi 2, untuk suhu rendah dan suhu tinggi

6. Pertama mengambil data untuk channel 1 dengan suhu rendah, dimana melakukan pengaturan pada Fluke/sebagai kalibrator dimulai dari suhu $0^{\circ} \mathrm{C}-100^{\circ} \mathrm{C}$ dengan kelipatan 10 maka akan didapat 11 buah data.

7. Pengambilan data dimulai dengan mengaktifkan tombol "start" pada LabVIEW dengan $3 x$ pengulangan lalu catat hasilnya

8. Setelah selesai mengambil data untuk suhu rendah selanjutnya untuk channel 1 dengan suhu tinggi dimana melakukan pengaturan pada Fluke/sebagai kalibrator dimulai dari suhu $0^{\circ} \mathrm{C}-500^{\circ} \mathrm{C}$ dengan kelipatan 50 maka akan didapat 11 buah data juga.

9. Ulangi kembali langkah 7, selanjutnya ambil data untuk channel 2 dengam memindahkan penghubung termokopel tipe-K ke channel 2 dan sisi lainnya tetap pada termometer digital Fluke.

10. Ulangi kembali langkah $6-8$. Pengambilan data kalibrasi program akuisis data selesai dilakukan.

\section{HASIL DAN PEMBAHASAN}

\section{Hasil Perhitungan Kalibrasi NI cDAQ 91}

Setelah selesai melakukan pengambilan data untuk kalibrasi program akuisisi data, maka didapatlah data hasil dari pengukuran temperatur NI cDAQ 91 untuk channel 1 dan channel 2. Selanjutnya data dari channel 1 dan channel 2 tersebut diproses dengan melakukan perhitungan kalibrasi. Perhitungan kalibrasi tersebut dilakukan penulis dengan memindahkan data yang ada ke dalam Microsoft Excel agar data lebih mudah untuk dilakukan perhitungan dengan kelebihan yang ada dalam Microsoft Excel tersebut dengan memanfaaatkan fungsifungsi yang telah tersedia. Pada Lampiran 1 dapat dilihat hasil dari data kalibrasi channel 1, dimana tabel yang sebelah kiri kebawah menunjukkan hasil data kalibrasi untuk suhu rendah dimulai dari temperatur $0^{\circ} \mathrm{C}-100^{\circ} \mathrm{C}$ yang diatur pada Fluke sebagai setpoint nya, sedangkan tabel sebelah kanan kebawah menunjukkan hasil data kalibrasi untuk suhu rendah dimulai dari temperatur $0^{\circ} \mathrm{C}-100^{\circ} \mathrm{C}$ yang diatur pada Fluke sebagai setpoint nya juga.

Setiap setpoint terdapat 3 data, karena sebelumnya dilakukan 3x pengulangan yaitu penunjuk standar Fluke terhadap penunjuk temperatur di tampilan LabVIEW. Kemudian data-data tersebut dicari rata-ratanya, standard deviasi dan juga besar koreksi yang didapat. Langkah selanjutnya mencari setiap komponen ketidakpastian (U) dari setiap 
setpoint. Komponen ketidakpastiaan tersebut terdiri dari:

- U1 : Ketidakpastiaan baku yang diproleh dari standar deviasi alat

- U2 : Ketidakpastiaan baku yang diproleh dari standar deviasi standard

- U3 : Ketidakpastiaan baku Termometer standar Fluke

- U4 : Ketidakpastiaan baku karena daya baca dari indikator Termometer standar Fluke

- U5 : Ketidakpastiaan baku karena daya baca dari alat atau NI cDAQ 91

- Uc : Ketidakpastiaan baku gabungan

- U : Ketidakpastiaan bentangan

Setiap komponen ketidakpastiaan tersebut dicari dengan memasukkan rumus pada kolom Microsoft Excel, sehingga didapatlah hasilnya. Data hasil dari data kalibrasi channel 2 perhitungan sama seperti data kalibrasi channel 1, yang membedakannya hanyalah data hasil temperatur yang didapat. Namun, perbedaan temperaturnya tidak terlalu jauh dikarena setpoint yang diatur juga sama, baik untuk suhu rendah maupun suhu tinggi.

Setelah data kalibrasi channel 1 dan channel 2 selesai dicari sampai nilai ketidakpastiaan bentangan, selanjutnya membuat laporan hasil kalibrasi akhir untuk kedua channel suhu rendah maupun suhu tinggi yang hasilnya dapat dilihat pada tabel dibawah ini.

Tabel 1. Data Hasil Kalibrasi Channel 1 suhu rendah

\begin{tabular}{|c|c|c|c|c|c|c|c|c|c|c|c|}
\hline \multicolumn{10}{|c|}{ HASIL KALIBRASI } & & \\
\hline \multicolumn{12}{|c|}{ Channel 1 dengan suhu rendah $0^{\circ} \mathrm{C}-100^{\circ} \mathrm{C}$} \\
\hline & \multirow[t]{2}{*}{ Set point } & & Temp & eratur & \multirow{2}{*}{ koreksi } & & \multirow{2}{*}{\multicolumn{3}{|c|}{ Ketidakpastian }} & \multicolumn{2}{|c|}{ Hasil Ketidakpastian } \\
\hline & & & \multicolumn{2}{|c|}{ Aktual Alat/ DAS } & & & & & & $(+)$ & $(-)$ \\
\hline 0 & ${ }^{\circ} \mathrm{C}$ & 0 & 0.00 & ${ }^{\circ} \mathrm{C}$ & 0.00 & ${ }^{\circ} \mathrm{C}$ & \pm & 0.1287 & ${ }^{\circ} \mathrm{C}$ & 0.1321 & -0.1254 \\
\hline 10 & ${ }^{\circ} \mathrm{C}$ & 10 & 10.05 & ${ }^{\circ} \mathrm{C}$ & -0.05 & ${ }^{\circ} \mathrm{C}$ & \pm & 0.2621 & ${ }^{\circ} \mathrm{C}$ & 10.3088 & 9.7846 \\
\hline 20 & ${ }^{\circ} \mathrm{C}$ & 20 & 20.03 & ${ }^{\circ} \mathrm{C}$ & -0.03 & ${ }^{\circ} \mathrm{C}$ & \pm & 0.1887 & ${ }^{\circ} \mathrm{C}$ & 20.2187 & 19.8413 \\
\hline 30 & ${ }^{\circ} \mathrm{C}$ & 30 & 30.08 & ${ }^{\circ} \mathrm{C}$ & -0.08 & ${ }^{\circ} \mathrm{C}$ & \pm & 0.0947 & ${ }^{\circ} \mathrm{C}$ & 30.1747 & 29.9853 \\
\hline 40 & ${ }^{\circ} \mathrm{C}$ & 40 & 40.09 & ${ }^{\circ} \mathrm{C}$ & -0.09 & ${ }^{\circ} \mathrm{C}$ & \pm & 0.0947 & ${ }^{\circ} \mathrm{C}$ & 40.1814 & 39.9920 \\
\hline 50 & ${ }^{\circ} \mathrm{C}$ & 50 & 50.08 & ${ }^{\circ} \mathrm{C}$ & -0.08 & ${ }^{\circ} \mathrm{C}$ & \pm & 0.0673 & ${ }^{\circ} \mathrm{C}$ & 50.1473 & 50.0127 \\
\hline 60 & ${ }^{\circ} \mathrm{C}$ & 60 & 60.05 & ${ }^{\circ} \mathrm{C}$ & -0.05 & ${ }^{\circ} \mathrm{C}$ & \pm & 0.0702 & ${ }^{\circ} \mathrm{C}$ & 60.1202 & 59.9798 \\
\hline 70 & ${ }^{\circ} \mathrm{C}$ & 70 & 70.03 & ${ }^{\circ} \mathrm{C}$ & -0.03 & ${ }^{\circ} \mathrm{C}$ & \pm & 0.0785 & ${ }^{\circ} \mathrm{C}$ & 70.1052 & 69.9481 \\
\hline 80 & ${ }^{\circ} \mathrm{C}$ & 80 & 80.01 & ${ }^{\circ} \mathrm{C}$ & -0.01 & ${ }^{\circ} \mathrm{C}$ & \pm & 0.0785 & ${ }^{\circ} \mathrm{C}$ & 80.0919 & 79.9348 \\
\hline 90 & ${ }^{\circ} \mathrm{C}$ & 90 & 89.99 & ${ }^{\circ} \mathrm{C}$ & 0.01 & ${ }^{\circ} \mathrm{C}$ & \pm & 0.1121 & ${ }^{\circ} \mathrm{C}$ & 90.0988 & 89.8746 \\
\hline 100 & ${ }^{\circ} \mathrm{C}$ & 100 & 99.94 & ${ }^{\circ} \mathrm{C}$ & 0.06 & ${ }^{\circ} \mathrm{C}$ & \pm & 0.0901 & ${ }^{\circ} \mathrm{C}$ & 100.0301 & 99.8499 \\
\hline
\end{tabular}


Tabel 2. Data Hasil Kalibrasi Channel 1 suhu tinggi

\begin{tabular}{|c|c|c|c|c|c|c|c|c|c|c|}
\hline \multicolumn{11}{|c|}{ Channel 1 dengan suhu tinggi $0^{\circ} \mathrm{C}-500^{\circ} \mathrm{C}$} \\
\hline \multicolumn{2}{|c|}{ Set point } & \multirow{2}{*}{\multicolumn{2}{|c|}{$\begin{array}{c}\text { Temperatur } \\
\text { Aktual Alat/ DAS }\end{array}$}} & \multirow{2}{*}{ koreksi } & & \multirow{2}{*}{\multicolumn{3}{|c|}{ Ketidakpastian }} & \multicolumn{2}{|c|}{ Hasil Ketidakpastian } \\
\hline & & & & & & & & & $(t)$ & (H) \\
\hline 0 & ${ }^{\circ} \mathrm{C}$ & 0.10 & ${ }^{\circ} \mathrm{C}$ & $\cdot 0.10$ & ${ }^{\circ} \mathrm{C}$ & \pm & 0.3995 & ${ }^{\circ} \mathrm{C}$ & 0.4961 & -0.3028 \\
\hline 50 & ${ }^{\circ} \mathrm{C}$ & 50.16 & ${ }^{\circ} \mathrm{C}$ & -0.16 & ${ }^{\circ} \mathrm{C}$ & \pm & 0.3828 & ${ }^{\circ} \mathrm{C}$ & 50.5461 & 49.7806 \\
\hline 100 & ${ }^{\circ} \mathrm{C}$ & 100.11 & ${ }^{\circ} \mathrm{C}$ & -0.11 & ${ }^{\circ} \mathrm{C}$ & \pm & 0.3738 & ${ }^{\circ} \mathrm{C}$ & 100.4871 & 99.7396 \\
\hline 150 & ${ }^{\circ} \mathrm{C}$ & 150.17 & ${ }^{\circ} \mathrm{C}$ & $\cdot 0.17$ & ${ }^{\circ} \mathrm{C}$ & \pm & 0.3932 & ${ }^{\circ} \mathrm{C}$ & 150.5666 & 149.7801 \\
\hline 200 & ${ }^{\circ} \mathrm{C}$ & 200.11 & ${ }^{\circ} \mathrm{C}$ & -0.11 & ${ }^{\circ} \mathrm{C}$ & \pm & 0.3952 & ${ }^{\circ} \mathrm{C}$ & 200.5052 & 199.7148 \\
\hline 250 & ${ }^{\circ} \mathrm{C}$ & 250.15 & ${ }^{\circ} \mathrm{C}$ & -0.15 & ${ }^{\circ} \mathrm{C}$ & \pm & 0.3986 & ${ }^{\circ} \mathrm{C}$ & 250.5453 & 249.7480 \\
\hline 300 & ${ }^{\circ} \mathrm{C}$ & 300.23 & ${ }^{\circ} \mathrm{C}$ & -0.23 & ${ }^{\circ} \mathrm{C}$ & \pm & 0.3723 & ${ }^{\circ} \mathrm{C}$ & 300.5990 & 299.8543 \\
\hline 350 & ${ }^{\circ} \mathrm{C}$ & 350.14 & ${ }^{\circ} \mathrm{C}$ & $\cdot 0.14$ & ${ }^{\circ} \mathrm{C}$ & \pm & 0.3695 & ${ }^{\circ} \mathrm{C}$ & 350.5128 & 349.7739 \\
\hline 400 & ${ }^{\circ} \mathrm{C}$ & 399.99 & ${ }^{\circ} \mathrm{C}$ & 0.01 & ${ }^{\circ} \mathrm{C}$ & \pm & 0.1707 & ${ }^{\circ} \mathrm{C}$ & 400.1607 & 399.8193 \\
\hline 450 & ${ }^{\circ} \mathrm{C}$ & 449.98 & ${ }^{\circ} \mathrm{C}$ & 0.02 & ${ }^{\circ} \mathrm{C}$ & \pm & 0.1632 & ${ }^{\circ} \mathrm{C}$ & 450.1465 & 449.8201 \\
\hline 500 & ${ }^{\circ} \mathrm{C}$ & 499.97 & ${ }^{\circ} \mathrm{C}$ & 0.03 & ${ }^{\circ} \mathrm{C}$ & \pm & 0.1620 & ${ }^{\circ} \mathrm{C}$ & 500.1286 & 499.8047 \\
\hline
\end{tabular}

Pada kedua tabel di atas merupakan hasil channel 1, untuk channel 2 tidak dilampirkan karena hasilnya sama. Terlihat hasil kalibrasi yang mana nilai ketidakpastiaan dari kedua channel telah didapat sebelumnya kemudian dicari \pm hasil ketidakpastiannya.

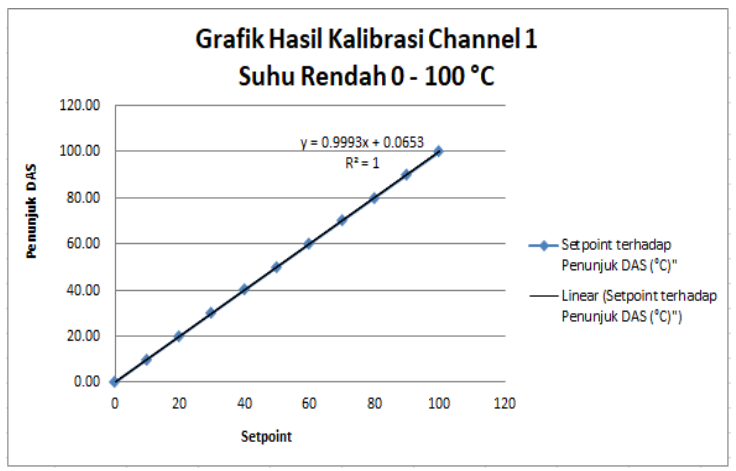

Gambar 5. Hasil kalibrasi Channel 1 suhu rendah

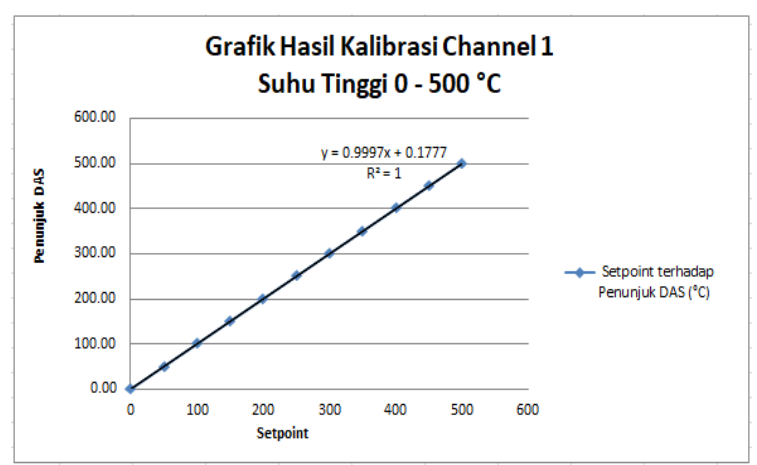

Gambar 6. Hasil kalibrasi Channel 1 suhu tinggi

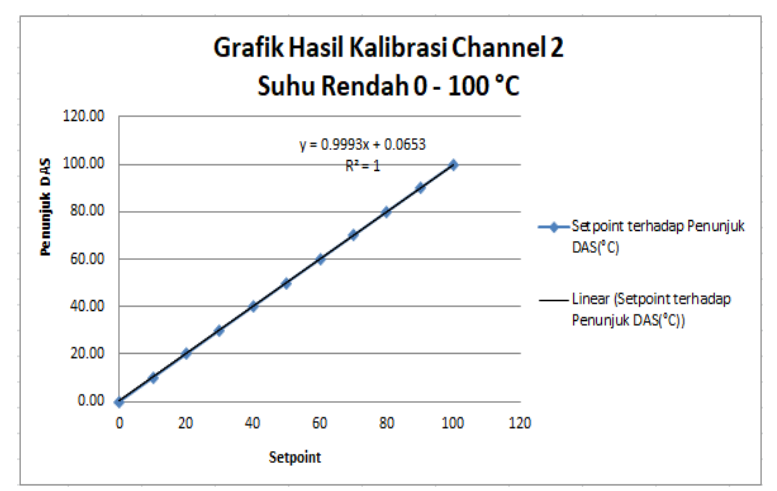

Gambar 7. Hasil kalibrasi Channel 2 suhu rendah

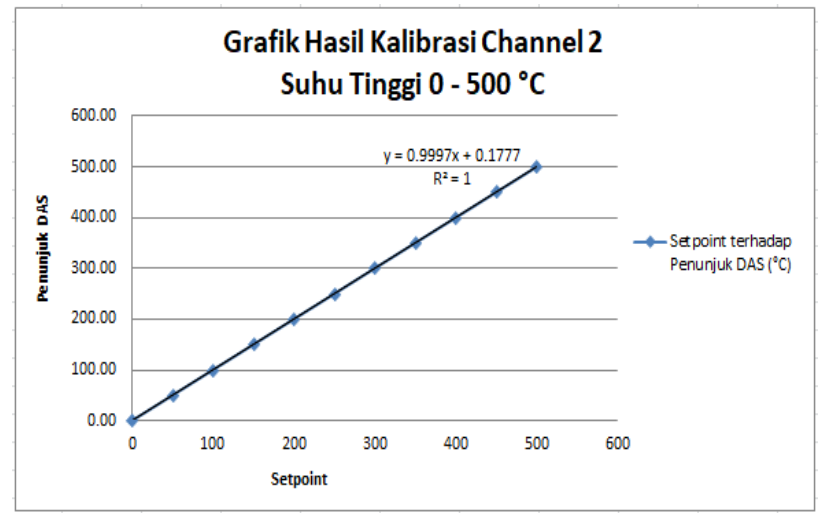

Gambar 8. Hasil kalibrasi Channel 2 suhu tinggi

Gambar 5, 67 dan 8 merupakan hasil kalibrasi channel 1 dan 2. Dari keempat 
grafik tersebut terlihat bahwa grafik membentuk garis linear dimana nilai setpoint terhadap penunjuk DAS hampir sama. Data kalibrasi yang didapat pada channel 1 dan channel 2 juga menghasilkan nilai yang tidak terlalu berbeda, sehingga ketika ketiga data setiap setpoint yang dicari dirata-ratakan hasilnya juga hampir sama. Setelah dicari setiap komponen katidakpastiaanya sampai dengan ketidakpastiaan bentangan juga maka hasil data cahnnel 1 dan channel 2 menghasilkan nilai yang sama, hal tersebut juga terjadi karena pembulatan yang dilakukan. Dalam Tabel 1 dan 2 juga telah dicari nilai hasil ketidakapastiaan yang didapat paling kecil adalah $0.0673^{\circ} \mathrm{C}$ terdapat pada setpoint dengan temperatur $50^{\circ} \mathrm{C}$ pada suhu rendah channel 1 dan channel 2, sedangkan nilai hasil ketidakpastiaan yang didapat paling besar hanya $0.3995^{\circ} \mathrm{C}$ terapat pada setpoint dengan temperatur $0^{\circ} \mathrm{C}$ pada suhu tinggi channel 1 dan channel 2.

\section{KESIMPULAN}

Perkembangan sistem akuisisi data telah sampai ketahap tertentu sehingga dapat membandingkan hasil pengukuran temperatur dari termokopel yang tercatat berupa akuisisi data NI cDAQ 91 dengan pengukuran alat ukur standar thermometer digital Fluke. Ternyata data yang didapat tidak berbeda jauh. Dari hasil ketidakpastiaan yang didapat tidak mencapai temperatur $1^{\circ} \mathrm{C}$ artinya data hasil kalibrasi tersebut dapat dipercaya dengan kesalahan kurang dari $1{ }^{\circ} \mathrm{C}$. Grafik hasil data kalibrasi yang didapat juga membentuk linear artinya data kalibrasi tersebut sesuai jangkauan dari setpoint yang telah ditentukan, artinya modul NI cDAQ 91 yang telah dikembangkan siap untuk digunakan dalam pengambilan data eksperimen termohidrolika.

\section{DAFTAR PUSTAKA}

1. SITI MARIAM, dkk. Kalibrasi Termokopel Tipe-K Pada Bagian Uji Heating-03 Menggunakan cDAQ-9188. Sigma Epsilon ISSN 0853-9103. 2013. 17: 162-163.

2. SUGIARTO, I., THIANG DAN SISWANTO, T. J. Desain dan Implementasi Modul Akuisisi Data sebagai Alternatif Modul DAQ LabVIEW. Jurnal Teknik Elektro. 2008. (8)1: 30.

3. AGUS NUR RACHMAN dan NURSINTA ADI WAHANANI. Pengembangan Sistem Instrumentasi Thermobath dan Akuisisi Data Termokopel Tipe K. Sigma Epsilon, ISSN 0853-9103. 2016. 20: 33-34.

4. KUSSIGIT SANTOSA. Pengembangan Sistem Akuisisi Data Tekanan Dan Temperatur Pada Fespeco Menggunakan Ni Crio 9074. Sigma Epsilon, ISSN 08539103. 2013. 17(2): 80-81. 
5. TAUFIQ HIDAYAT. Penggunaan

Labview Untuk Simulasi Sistem Kontrol Keamanan Rumah. Program Studi Teknik Mesin Fakultas Teknik Universitas Muria Kudus. 2015. 7(1): 2-3.

6. EDISON, A.MARIATMO dan SUJARWONO, Pembuatan Kalibrator Meter Reaktivitas dengan Sistem DAQ Berbasis Pc. Prosiding PPI - PDIPTN Batan. Yogyakarta. 2007.

7. SUPRIANTO. Pengertian Termokopel (Thermocouple) dan Prinsip Kerjanya [Diakses: 11 Juni 2018]. Tersedia dari: http:// blog. unnes.ac.id/ antosupri /pengertian -termokopel- thermocouple dan prinsip-kerjanya/.

8. GINUMERIK. Pengertian Kalibrasi [Diakses: 25 Juni 2018]. Tersedia dari: http://www. ginumerik. com / artikel/ 12 pengertian-kalibrasi.

9. A. ZULFIRA. Ketidakpastian dalam Pengukuran Fisika [Diakses: 25 Juni 2018]. Tersedia dari: http:// daraullya. 2015/ 01/ ketidakpastian- dalampengukuran fisika.html.

10. Batan. Fasilitas Termohidrolika [Diakses: 4 Juli 2018]. Tersedia dari: http://www.batan.go.id. 